\title{
Effect of protected methionine supplementation on milk production and reproduction in first calf heifers
}

\author{
Hosam H. Titi, Saleh I. Azzam and Mufeed A. Alnimer \\ Department of Animal Production, Faculty of Agriculture, University of Jordan, Amman, Jordan
}

\begin{abstract}
Sixty Holstein heifers ( 30 days in milk) were used to examine the effects of protected methionine on milk production, milk composition and reproduction performance up to 100 days post-partum. Heifers were randomly divided into two dietary treatment groups (30 each) receiving either 14 or $16 \%$ crude protein. Heifers of each treatment group were assigned into three subgroups with a daily supplementation of 0,15 or $25 \mathrm{~g} / \mathrm{hd} / \mathrm{d}$ of rumen protected methionine. Diet fed was a total mixed ration consisting of fresh alfalfa, corn silage and a concentrate mixture. In addition, alfalfa hay was offered ad libitum during the whole experimental period.

Supplementation of the $14 \%$ crude protein diet with $25 \mathrm{~g} / \mathrm{hd} / \mathrm{d}$ rumen protected methionine increased $(P<0.05)$ milk yield, fat corrected milk, energy corrected milk, percentages of milk fat, total solids and casein as well as yields of milk fat and protein compared to those without or with $15 \mathrm{~g} / \mathrm{hd} / \mathrm{d}$ rumen protected methionine. Dry matter intake, feed to fat corrected milk ratio, body weight and body condition score were also improved $(P<0.05)$ with the supplementation of rumen protected methionine at the same level compared to the other levels. Meanwhile, milk protein percentage and feed to milk ratio were unaffected. At $16 \%$ crude protein, milk yield, fat corrected milk, energy corrected milk, fat $\%$, yields of fat and protein as well as feed:milk ratio and feed

:fat corrected milk ratio were all increased $(P<0.05)$ with rumen protected methionine supplementation regardless of its level. However, milk content of protein and total solids were unaffected. Casein was only increased $(P<0.05)$ when rumen protected methionine was supplemented to this diet at $15 \mathrm{~g} / \mathrm{hd} / \mathrm{d}$. Dry matter intake, final body weight and body condition score were increased $(P<0.05)$ when rumen protected methionine was supplemented at $25 \mathrm{~g} / \mathrm{hd} / \mathrm{d}$. Reproductive performance measurements were unaffected
\end{abstract}


by rumen protected methionine supplementation to both diets. These results indicate that supplementation of rumen protected methionine would improve milk production performance at both dietary protein levels with no effect on reproductive performance.

Keywords: heifers, protected methionine, milk production, reproductive performance

Abbreviations: CP: crude protein, ECM: energy corrected milk, FCM: fat corrected milk, RPMet: rumen protected methionine

\section{Introduction}

Compared to milk protein or the amino acid profile of ruminal microbes, feeds are often deficient in lysine and methionine contents (NRC 2001). The protein which reaches the small intestine is adequate in cystine but deficient in methionine, making it the first limiting amino acid for high yielding dairy cows (Lara et al. 2006). Rumen microbial protein synthesis cannot supply sufficient quantities of amino acids to meet the requirements of cows producing large quantities of milk (Polan et al. 1991, Ali et al. 2009). Therefore, ruminally undegradable protein must be provided in the diet to maximize the amount of amino acids available for absorption in the intestine (Samuelson et al. 2001, Leonardi et al. 2003).

Many of the studies that evaluated production responses of dairy cattle to protein supplementation have not considered the lysine and methionine content across treatments but have used diets formulated for crude protein (CP) or ruminally undegradable protein content only (NRC 2001). In such studies, it was not clear whether production responses were the effect of ruminally undegradable protein content or amino acid supply. Further studies are still needed to consider amino acid supply in order to determine the causes of responses to changes in protein feeding. At the same time, Bobe (1997) and (Trinacty et al. 2009) revealed that high CP intake, in particular high intake of methionine, in early lactation is necessary for stimulating maximum milk production.

Many researchers reported inconsistent results concerning the effect of rumen protected methionine (RPMet) supplementation on milk yield. Numerous studies reported no increase in milk yield when RPMet was supplemented to dairy cows (Overton et al. 1998, Socha et al. 2005, Ali et al. 2009). Other studies did not show any response in milk protein percentage or yield with the addition of RPMet (Polan et al. 1991, Overton et al. 1998, Socha et al. 2005, Ali et al. 2009).

Milk fat percentage has been reported to be increased when RPMet was supplemented (Samuelson et al. 2001, Trinacty et al. 2009). Lara et al. (2006) showed no effects on fat content of the milk when dairy cows received RPMet supplementation.

A limited number of studies discussed the effects of methionine supplementation on reproductive performance. Ardalan et al. (2010) reported that the reproductive performance of cows fed methionine hydroxy analog was improved. Dietary supplementation with RPMet in the first 90 days of lactation did not affect the time to first observed oestrus, days to first service, services per conception, calving interval or days of retained placenta and metritis (Rogers et al. 1989, Polan 1991, Ardalan et al., 2010). However, the same methionine source increased the days to first conception, services per conception, incidences of cysts and did not affect reproductive cycling of dairy cows (Bobe 1997, Ardalan et al. 2010). 
Most of the above mentioned studies were obtained with adult dairy cows and none were with first calf heifers. Heifers have higher $\mathrm{CP}$ requirements to sustain growth requirements (NRC 2001). Therefore, the objective of this study was to investigate the effects of RPMet supplementation on early lactation performance and reproductive performance of first calf dairy heifers from day 30 to day 100 post-partum.

\section{Material and methods}

\section{Dietary treatments and animal care}

Sixty Holstein Friesian first calf heifers were randomly assigned into two dietary treatment groups (14 and $16 \%$ CP) with 30 cows in each group. Each treatment group was randomly divided into three subgroups of equal numbers of animals. The subgroups were supplemented with 0,15 or $25 \mathrm{~g} / \mathrm{hd} / \mathrm{d}$ of RPMet (MET55; DL-Methionine $55 \%$, hydrogenated vegetable oil $45 \%$; JEFO Nutrition Inc., St-Hyacinthe, Québec, Canada). Diets were balanced according to the NRC (2001) requirements.

The experiment started on day $30 \pm 3$ post-partum and continued up to 100 days postpartum. The average body weight of heifers at the beginning of experiments was $453 \pm 4 \mathrm{~kg}$ and after 100 days it was $466 \pm 4 \mathrm{~kg}$. Body condition score was measured on a five-point scale (1=emaciated to $5=$ obese) (Edmonson et al. 1989).

Treatment diets were offered as a total mixed ration. Diets were based on corn silage, alfalfa hay, $44 \%$ soybean, wheat bran, barley grain and corn grain. Ingredient per cent composition of the experimental diets is listed in Table (1) and chemical analysis of these rations is listed in Table (2). Cows were fed at the level of $19 \mathrm{~kg}$ dry matter $/ \mathrm{hd} / \mathrm{d}$ of the total mixed ration. In addition, alfalfa hay was offered ad libitum during the whole experimental period and average individual consumption was estimated. Daily intake of the hay was recorded on group basis. Feed was offered individually after milking three times daily with free access to water. The methionine supplement for each group was mixed with the total mixed ration at mixing time and diets were prepared every day. Samples for analysis were taken after each mixing and kept frozen until time of analysis. All cows were handled and housed in free stall shadow barns.

Table 1

Ingredient composition of the experimental diets

\begin{tabular}{lcc}
\hline Ingredients & $14 \%$ CP & $16 \%$ CP \\
\hline Barley & 28 & 25 \\
Soybean meal, 44\% & 8 & 13.6 \\
Corn grain & 13 & 13.6 \\
Wheat bran & 13 & 13.6 \\
Fresh alfalfa & 10 & 8 \\
Corn silage & 24.73 & 22.93 \\
Wheat straw & 3 & 3 \\
Salt & 0.1 & 0.1 \\
Sodium carbonate & 0.05 & 0.05 \\
Limestone & 0.1 & 0.1 \\
Mineral and vitamin mix* & 0.02 & 0.02 \\
\hline
\end{tabular}

*Ruminant Premix (Nutristar International, Cergy-Pontoise, France) 1 kg contains: Vitamin A 5000000 IU, Vitamin D3 $1000000 \mathrm{IU}$, Vitamin E $10000 \mu \mathrm{g}$, Choline Chlorides $4000 \mu \mathrm{g}$, Manganese $25000 \mu \mathrm{g}$, Copper $2000 \mu \mathrm{g}$, Zinc $10000 \mu \mathrm{g}$, Selenium $0.200 \mu \mathrm{g}$, Cobalt $0.250 \mu \mathrm{g}$, Iron $25000 \mu \mathrm{g}$, lodine $0.5000 \mu \mathrm{g}$, Phosphorus $15000 \mu \mathrm{g}$, Antioxidant $11200 \mu \mathrm{g}$ 
Table 2

Chemical composition of the experimental diets

\begin{tabular}{lcccc}
\hline Chemical composition & $14 \% \mathrm{CP}$ & $16 \% \mathrm{CP}$ & Alfalfa hay & Corn silage \\
\hline Dry matter, \% & 68 & 70 & 89 & 37 \\
Crude protein, \% & 14 & 16 & 13.8 & 8 \\
Neutral detergent fibre, \% & 36.6 & 37 & 43 & 49 \\
Acid detergent fibre, \% & 19.6 & 20 & 32 & 31 \\
Ash, \% & 6 & 4.3 & 7 & 4.5 \\
Net energy of lactation, Mcal/kg & 1.6 & 1.7 & 1.22 & 1.5 \\
\hline
\end{tabular}

Cows were milked three times daily at 8-h intervals using a complete computerized milking system (Herringbone parlour 2x12; Delaval, Tumba, Sweden). Milk production of each cow was recorded after each milking time.

On day $30 \pm 3$ each heifer was rectally palpated to ensure uterus and ovaries were normal. Hormonal protocol was applied to all cows to synchronize oestrus starting on day $45 \pm 3$ post-partum with a $25 \mathrm{mg}$ intramuscular injection of prostaglandin $\left(\mathrm{PGF}_{2 a^{\prime}}\right.$ Lutalyse, Pfizer, Belgium). Heifers that did not show oestrus after the first $\mathrm{PGF}_{2 \mathrm{a}}$ injection received another one on day $57 \pm 3$. One heifer of each subgroup was excluded from the synchronization protocol due to reproductive disorders.

Oestrus was determined by visually monitoring the heifers throughout the day. Heifers that returned oestrus after the first artificial insemination were re-inseminated, while those found non-pregnant on day 50 post artificial insemination were injected with PGF $_{2 a}$ and inseminated after observed oestrus. Heifers were bred from a single ejaculate of a single Holstein sire (Lyster, Semex, Canada). Insemination was conducted approximately $12 \mathrm{~h}$ after heifers were observed in standing heat. A single inseminator was responsible for breeding all heifers in the study. Pregnancies were determined by rectal palpation on day 50 post artificial insemination. Observation was continued beyond the end of the experimental period to monitor the pregnancy results up to the third insemination. Reproductive data were recorded for days to first, second and third insemination and pregnancy rates.

\section{Sample collection and analytical procedures}

During the experimental period, milk was sampled weekly from each cow in the experiment and analysed for percentage of milk fat, protein and total solids (AOAC 1995). Fat was determined using the Gerber method, while protein content of both milk and feed was determined by Kjeldahl method ( $N \times 6.38$ ). Casein was determined according to AOAC (1995).

Feed samples were dried at $105^{\circ} \mathrm{C}$ overnight. Ash was determined by burning sample in a muffle furnace at $650^{\circ} \mathrm{C}$. Neutral detergent fibre and acid detergent fibre were determined following the procedure of Van Soest et al. (1991).

Energy corrected milk was determined following the equation of AbuGhazaleh et al. (2002):

$$
E C M=(0.3246 \times \text { milk yield })+(12.86 \times \text { fat yield })+(7.04 \times \text { protein yield })
$$

Fat corrected milk (4\%) was determined using the equation provided by the NRC (2001) as follows:

$$
4 \% F C M=(0.4 \times \text { milk yield })+(15 \times \text { fat yield })
$$




\section{Statistical analysis}

The effects of supplementing RPMet to the diet on total dry matter intake, milk yield and milk composition were analysed as a repeated measure analysis using the MIXED procedure of SAS V7 (SAS Institute Inc., Cary, NC, USA). Individual animal (heifer) was considered as the experimental unit for data analysis. Data of production response collected in the preexperimental period were used as a covariate for statistical model that included CP level $(14 \%$ and $16 \%)$, methionine level $(0,15$ and $25 \mathrm{~g} / \mathrm{hd} / \mathrm{d})$ and period effect. For reproductive performance, the statistical model was protein and methionine levels and their interactions. Also, Chi square test was applied for pregnancy test data. All data are presented as least squares means and separated using the protected least significant difference tested at $P<0.05$ (Steel \& Torrie 1986).

\section{Results and discussion}

\section{Milk yield and composition}

Milk production during the first $30-\mathrm{d}$ period was used as a covariate during analysis. Heifers fed the $14 \% \mathrm{CP}$ diet had maximum $(P<0.05)$ milk production and fat corrected milk $(4 \%$ FCM) at level of $25 \mathrm{~g} / \mathrm{hd} / \mathrm{d}$ RPMet supplementation (Table 3). When fed the $16 \%$ CP diet, both parameters increased $(P<0.05)$ linearly as RPMet in the diet increased. Milk production was analysed according to different periods of the experiment: 5-8 week (time of expected peak lactation) and 9-14 week (remaining period of the study). During both stages of the experiment, maximum $(P<0.05)$ daily milk production in heifers fed the $14 \% \mathrm{CP}$ diet was found with $25 \mathrm{~g} / \mathrm{hd} / \mathrm{d}$ RPMet while in those fed the $16 \% \mathrm{CP}$ diet, average daily milk production increased $(P<0.05)$ linearly with RPMet level in the diet.

Table 3

Average milk production and composition of heifers fed deferent levels of protected methionine in their diets

\begin{tabular}{|c|c|c|c|c|c|c|c|c|}
\hline \multirow{2}{*}{$\begin{array}{l}\text { Diets } \\
\text { Methionine } \mathrm{g} / \mathrm{d}\end{array}$} & \multirow[b]{2}{*}{0} & \multicolumn{2}{|l|}{$14 \%$ CP } & \multicolumn{3}{|c|}{$16 \%$ CP } & \multirow[b]{2}{*}{ SE } & \multirow[b]{2}{*}{$P$} \\
\hline & & 15 & 25 & 0 & 15 & 25 & & \\
\hline \multicolumn{9}{|l|}{ Milk yield } \\
\hline Total (5-14 week) & $21.12^{\mathrm{b}}$ & $21.30^{\mathrm{b}}$ & $22.62^{\mathrm{a}}$ & $22.84^{c}$ & $24.75^{b}$ & $25.97^{\mathrm{a}}$ & 0.154 & 0.001 \\
\hline 5-8 week & $21.59^{b}$ & $22.21^{b}$ & $23.29^{\mathrm{a}}$ & $23.17^{c}$ & $25.61^{b}$ & $27.04^{a}$ & 0.040 & 0.001 \\
\hline 9-14 week & $20.65^{b}$ & $20.39^{b}$ & $21.95^{\mathrm{a}}$ & $22.51^{c}$ & $23.89^{b}$ & $24.90^{\mathrm{a}}$ & 0.092 & 0.001 \\
\hline $4 \% \mathrm{FCM}^{2}$ & $19.24^{b}$ & $19.62^{b}$ & $21.27^{a}$ & $21.07^{c}$ & $23.10^{b}$ & $24.19^{a}$ & 0.162 & 0.001 \\
\hline Fat, $\%$ & $3.42^{c}$ & $3.49^{b}$ & $3.61^{\mathrm{a}}$ & $3.48^{b}$ & $3.54^{\mathrm{a}}$ & $3.55^{\mathrm{a}}$ & 0.016 & 0.001 \\
\hline Fat, kg/d & $0.72^{c}$ & $0.74^{b}$ & $0.81^{\mathrm{a}}$ & $0.79^{c}$ & $0.88^{b}$ & $0.92^{\mathrm{a}}$ & 0.007 & 0.001 \\
\hline Protein, \% & 3.10 & 3.13 & 3.10 & 3.04 & 3.03 & 3.08 & 0.023 & ns \\
\hline Protein, $\mathrm{kg} / \mathrm{d}$ & $0.65^{b}$ & $0.66^{b}$ & $0.70^{\mathrm{a}}$ & $0.69^{c}$ & $0.75^{b}$ & $0.80^{\mathrm{a}}$ & 0.007 & 0.001 \\
\hline Casein, $\%^{1}$ & $2.45^{b}$ & $2.50^{b}$ & $2.57^{\mathrm{a}}$ & $2.36^{b}$ & $2.40^{\mathrm{a}}$ & $2.35^{b}$ & 0.011 & 0.001 \\
\hline Total Solids, \% & $11.45^{\mathrm{b}}$ & $11.61^{\mathrm{ab}}$ & $11.79^{a}$ & 11.61 & 11.71 & 11.77 & 0.013 & 0.481 \\
\hline $\mathrm{ECM}^{3}$ & $20.70^{c}$ & $21.07^{b}$ & $22.68^{\mathrm{a}}$ & $22.43^{c}$ & $24.63^{b}$ & $25.89^{a}$ & 0.173 & 0.001 \\
\hline
\end{tabular}

a,b,cMeans with different superscripts within the same row are different $(P<0.05), \quad{ }^{1}$ Casein as \% of milk composition, ${ }^{2} 4 \% \mathrm{FCM}=(0.4 \times \mathrm{kg}$ milk $)+(15 \times \mathrm{fat} \mathrm{kg}),(\mathrm{NRC}, 1989),{ }^{3} \mathrm{ECM}=(0.3246 \times$ milk yield $)+(12.86 \times$ fat yield $)+(7.04 \times$ protein yield $)$, (AbuGhazaleh et al., 2002) 
Interaction of treatment $\times$ week on milk production is illustrated in Figures 1 and 2 . Although no differences were detected among heifers fed the 14\% CP diet (Figure 1), those supplemented with $25 \mathrm{~g} / \mathrm{hd} / \mathrm{d}$ RPMet were able to maintain higher and stable production during the first 4 weeks before starting to decline. Other heifers on the same diet exhibited declined milk production starting at week 2 or 3 of the experiment. In Figure 2, heifers fed $16 \%$ CP diet and $25 \mathrm{~g} / \mathrm{hd} / \mathrm{d}$ RPMet showed higher $(P<0.05)$ milk production during the first 4 weeks of the experiment. However, persistency of milk production was maintained for the first 4 weeks in heifers that received 25 and $15 \mathrm{~g} / \mathrm{hd} / \mathrm{d}$ RPMet but only for the first 3 weeks in the control heifers.

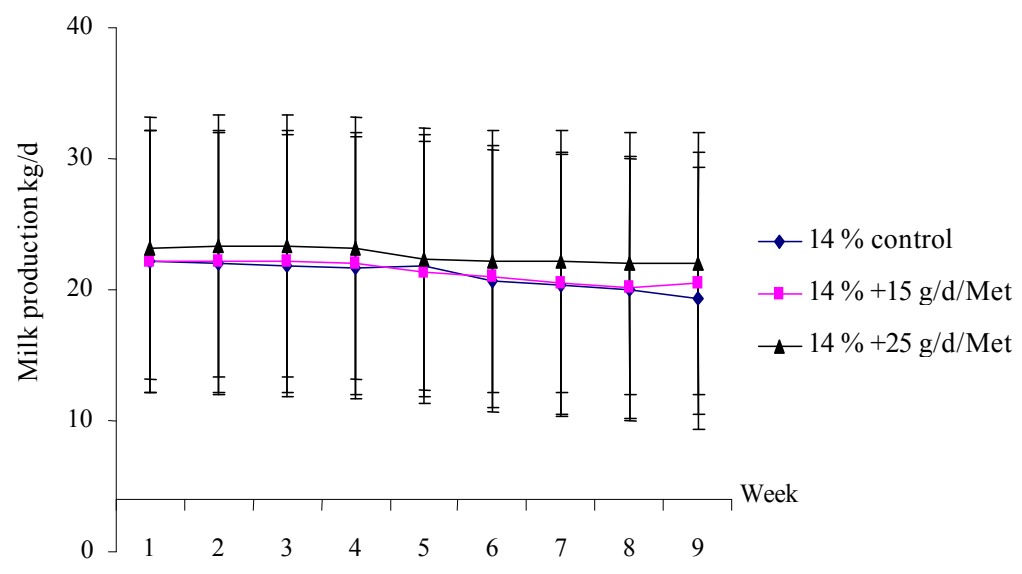

Figure 1

Effect of different levels of RPMet on average weekly milk yield of heifers fed a $14 \%$ CP diet. Data points represent weekly least squares means \pm SEM for $14 \%$ CP dietary treatments

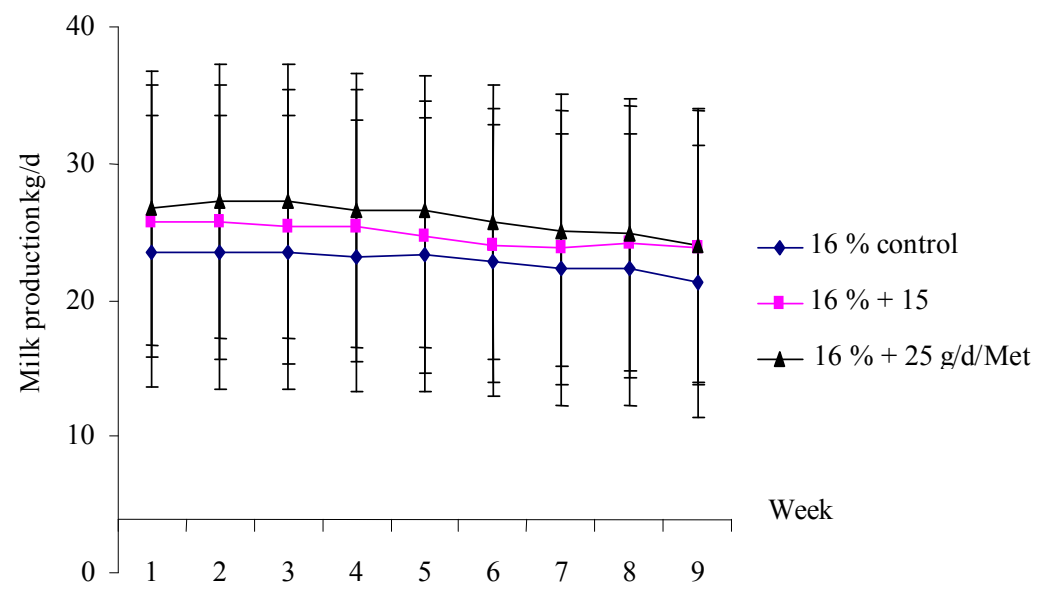

Figure 2

Effect of different levels of RPMet on average weekly milk yield of heifers fed a $16 \%$ CP diet. Data points represent weekly least squares means \pm SEM for $16 \%$ CP dietary treatments 
Production response of lactating dairy cows to supplemental RPMet is often controversial. The found increase in milk yield following RPMet supplementation to both diets agreed with Lara et al. (2006) and Kudrna et al. (2009). Moreover, Dinn et al. (1998) showed that feeding diets with $15 \%$ CP supplemented with RPMet supported milk production as much as feeding $18 \%$ CP without addition of amino acid. The positive response in milk production to RPMet would possibly indicate that methionine was mostly a limiting factor to production. Similar results indicated that methionine was a limiting amino acid for high milk production in dairy cows fed corn and soybean meal during early lactation (Samuelson et al. 2001, Lara et al. 2006, Ali et al. 2009, Benefield et al. 2009). The increased milk production of the $16 \%$ CP group confirms the dose-dependent response to supplemental methionine (Lara et al. 2006, Benefield et al. 2009).

In contrast, milk yield of dairy cows supplemented with RPMet was either decreased (Benefield et al. 2009), not changed or only minor effects were reported (Noftsger et al. 2005, Kudrna et al. 2009, Trinacty et al. 2009). Girard et al. (2005) reported that in a non-exhaustive review between 1993 and 2003, only 1 of 22 studies looking for the effect of RPMet to dairy cows showed increased milk production following supplementation. Differences in milk yield among experiments might be attributed to the degree to which methionine was limiting in the diets fed, an excess of amino acids, an imbalance in amino acids, increased intake of compounds used to protect the amino acids from ruminal degradation or other factors (Lara et al. 2006).

In the present case, the studied herd consisted of first calf heifers that have higher protein requirements than adult cows (NRC 2001). This might explain the positive response to RPMet supplementation when heifers were fed either diet (14\% or $16 \% \mathrm{CP})$ supplemented with $25 \mathrm{~g} / \mathrm{d}$ RPMet, or with $15 \mathrm{~g} / \mathrm{d}$ only when fed the $16 \%$ CP diet. Feeding diets with $14 \% \mathrm{CP}$ to growing heifers might be not adequate and limits the response to the $25 \mathrm{~g} / \mathrm{d}$ RPMet level that compensated partially the limited protein content of the diet. However, the $16 \% \mathrm{CP}$ diet seemed to be somehow nearly adequate and might had enabled heifers to present increased milk production with increased level of supplementation. However, Leonardi et al. (2003) found that RPMet can improve milk protein content to the same extent regardless of whether a diet with $14 \%$ or $18 \%$ CP was fed.

Milk fat content of heifers fed a $14 \%$ CP diet was increased $(P<0.05)$ with level of RPMet supplementation (Table 3), while it was higher $(P<0.05)$ in heifers fed the $16 \%$ CP diet regardless of the level RPMet. Fat yield followed a similar trend in both diets (14 and 16\% $\mathrm{CP}$ ) and increased with RPMet level in the diet. No differences were observed in average milk protein percentage of heifers fed either diet (14 or $16 \% \mathrm{CP}$ ) regardless of methionine level. Meanwhile, protein yield in milk of the $14 \%$ CP heifers was higher $(P<0.05)$ at $25 \mathrm{~g} /$ $\mathrm{hd} / \mathrm{d}$ RPMet level. Opposite to that, protein yield increased $(P<0.05)$ with RPMet level within heifers fed the $16 \%$ CP diet.

Total solids were higher $(P<0.05)$ in the milk of heifers that received $25 \mathrm{~g} / \mathrm{hd} / \mathrm{d}$ RPMet in the $14 \%$ CP diet, whereas no differences were observed among heifers fed the $16 \%$ CP diet. Energy corrected milk was increased $(P<0.05)$ with RPMet level in both diets. Milk casein of heifers fed the $14 \% \mathrm{CP}$ diet was higher $(P<0.05)$ with $25 \mathrm{~g} / \mathrm{hd} / \mathrm{d}$ but when fed the $16 \% \mathrm{CP}$ diet, casein was higher $(P<0.05)$ for those that received $15 \mathrm{~g} / \mathrm{hd} / \mathrm{d}$.

The general expectation is that the major effect of the inclusion of RPMet in the ration of dairy cows is that milk protein content and yield will often increase (Girard et al. 2005). 
Increased content and/ or yield of protein were reported earlier (Noftsger et al. 2005, Lara et al. 2006, Socha et al. 2008, Benefield et al. 2009, Kudrna et al. 2009, Trinacty et al. 2009) but in these experiments more cows were involved and longer periods of supplementation were used. However, Leonardi et al. (2003) reported that the addition of RPMet to diets of dairy cows does not always result in an increase of milk protein yield. No response in protein percentage or yield was observed with the addition of RPMet (Overton et al. 1998, Madsen et al. 2005, Socha et al. 2005, Kudrna et al. 2009). Inconsistent results are obviously due to many other factors interacting in this complex process, among them being the stage of lactation as well as the source, form and digestibility of protein that may play a very significant role (Ali et al. 2009, Kudrna et al. 2009).

Increased milk fat synthesis following feeding RPMet was reported previously (Samuelson et al. 2001, Benefield et al. 2009). On the other hand, no or low milk fat content was evident in many studies investigating the effects of RPMet supplementation (Samuelson et al. 2001, Girard et al. 2005; Lara et al. 2006, Trinacty et al. 2009).

The specific reason for the increased fat is unknown. However, several possibilities have been suggested. NRC (2001) reported that methionine supplementation would increase post-ruminal energy compounds (acetate) strongly associated with fat synthesis. Methionine may also increase de novo synthesis of short and medium chain fatty acids in the mammary gland or may act as a methyl donor for the synthesis of choline, which is essential for the synthesis of phospholipids that are required for the synthesis of chylomicrons and very low density lipoproteins (Girard et al. 2005, Benefield et al. 2009). Other studies proposed that methionine might serve as a substrate for triglyceride transport to the mammary gland (Madsen et al. 2005, Benefield et al. 2009). It is most likely that the increase in milk total solids, when cows were supplemented with RPMet, resulted from a combined increase in fat and protein concentration. Results of casein are in line with those from other experiments of Armentano et al. (1997), Girard et al. (2005) and Trinacty et al. (2009) who reported that the primary response to added methionine was increased secretion of casein and that the increased milk protein synthesis of cows fed rumen protected amino acids in some studies was mostly caused by increased synthesis of casein (Armentano et al. 1997).

Energy corrected milk is a function of milk fat and CP content. Therefore, the increase in ECM would be due mostly to the increase in both contents observed in both diets when supplemented with methionine, as well as to the increase in milk yield obtained with methionine supplementations. To our best knowledge, published literature available regarding the effect of RPMet on ECM is very scarce. Only Socha et al. $(2005,2008)$ showed no effect of RPMet on ECM values. Moreover, Ardalan et al. (2010) suggest that the increased ECM results from a positive impact of RPMet on milk energy output when early-lactation curve peaks and drops.

In both diets, daily feed intake ( $\mathrm{kg} \mathrm{DM} / \mathrm{d})$ was higher $(P<0.05)$ at $25 \mathrm{~g} / \mathrm{hd} / \mathrm{d}$ RPMet compared to the other two groups (Table 4). Increased dry matter intake following RPMet supplementation was reported by Trinacty et al. (2009) while it tended to increase linearly following RPMet supplementation as reported by Socha et al. (2008). However, others obtained reduced (Dinn et al. 1998, Benefield et al. 2009, Kudrna et al. 2009) or unaltered dry matter intake (Overton et al. 1998, Girard et al. 2005, Madsen et al. 2005, Noftsger et al. 2005, Lara et al. 2006). 
Table 4

Feed intake and body weigt of heifers fed different levels of protected methionine in their diets

\begin{tabular}{|c|c|c|c|c|c|c|c|c|}
\hline \multirow{2}{*}{$\begin{array}{l}\text { Diets } \\
\text { Methionine } \mathrm{g} / \mathrm{d}\end{array}$} & \multicolumn{3}{|c|}{$14 \% \mathrm{CP}$} & \multicolumn{3}{|c|}{$16 \% C P$} & \multirow[b]{2}{*}{ SE } & \multirow[b]{2}{*}{$P$} \\
\hline & 0 & 15 & 25 & 0 & 15 & 25 & & \\
\hline Number of animals & 10 & 10 & 10 & 10 & 10 & 10 & & \\
\hline Feed intake, $\mathrm{kg} \mathrm{DM} / \mathrm{d}$ & $21.45^{b}$ & $21.52^{b}$ & $22.46^{\mathrm{a}}$ & $22.62^{b}$ & $22.63^{b}$ & $23.28^{\mathrm{a}}$ & 0.07 & 0.001 \\
\hline Feed:Milk & 1.02 & 1.01 & 0.99 & $0.99^{b}$ & $0.91^{\mathrm{a}}$ & $0.90^{\mathrm{a}}$ & 0.01 & 0.001 \\
\hline FCM efficiency ${ }^{2}$ & $1.11^{\mathrm{a}}$ & $1.10^{\mathrm{a}}$ & $1.06^{b}$ & $1.07^{\mathrm{b}}$ & $0.98^{\mathrm{a}}$ & $0.96^{\mathrm{a}}$ & 0.01 & 0.001 \\
\hline Initial body weight, kg & 449.33 & 452.33 & 459.00 & 447.66 & 449.77 & 464.55 & & \\
\hline Final body weight, kg & $460^{\mathrm{b}}$ & $464^{b}$ & $473^{\mathrm{a}}$ & $459^{b}$ & $462^{b}$ & $478^{\mathrm{a}}$ & 3.40 & 0.001 \\
\hline Initial body condition score 3 & 2.65 & 2.66 & 2.71 & 2.62 & 2.73 & 2.77 & & \\
\hline Final body condition score & $2.70^{\mathrm{b}}$ & $2.72^{\mathrm{b}}$ & $2.77^{\mathrm{a}}$ & $2.71^{\mathrm{b}}$ & $2.78^{\mathrm{b}}$ & $2.84^{\mathrm{a}}$ & 0.02 & 0.001 \\
\hline
\end{tabular}

a, b, cMeans with different superscripts within the same row are different $(P<0.05)$, 'Feed:Milk: daily dry matter intake: daily milk production, $\mathrm{kg} / \mathrm{kg},{ }^{2}$ Fat corrected milk efficency $=\mathrm{kg}$ feed $/ \mathrm{kg} 4 \%$ fat corrected milk, ${ }^{3}$ Body condition score measured on a five-point scale with $1=$ emaciated and $5=$ obese (Edmonson et al., 1989)

Feed:milk ratio (feed efficiency) expressed as kg dry matter of daily intake perkg daily milk production showed no differences among heifers fed the $14 \%$ CP diet (Table 4). Those fed the $16 \%$ CP diet showed an improved $(P<0.05)$ ratio when supplemented with RPMet regardless its level. When expressed based on $4 \%$ FCM, heifers fed the $14 \%$ CP diet had the best $(P<0.05)$ ratio at $25 \mathrm{~g} / \mathrm{hd} / \mathrm{d}$ RPMet supplementation. Meanwhile, when fed the $16 \% \mathrm{CP}$ diet, the best ratio $(P<0.05)$ was achieved regardless of the RPMet level.

Final body weight and body condition score were higher $(P<0.05)$ for heifers that received $25 \mathrm{~g} / \mathrm{hd} / \mathrm{d}$ RPMet in both diets (Table 4). The increase in final body weight might be due to the increased dry matter intake observed in this experiment. Overton et al. (1996) indicated that dairy cows fed RPMet tended to have greater body weights. Noftsger \& St-Pierre (2003) and Lara et al. (2006) reported no change in body weight of dairy cows after supplementation with RPMet. Higher body weight and body condition score of cows that received $25 \mathrm{~g} / \mathrm{hd} / \mathrm{d}$ RPMet in both diets might indicate that supplementation with RPMet aided to improve these measures. This might suggest that increased levels of RPMet might favour more energy partition into body tissues (Samuelson et al. 2001). However, it should be noted that dietary effects on body weight may not be accurately reflected in experiments with short term experimental periods.

\section{Reproduction measurements}

Results on reproductive performance indicate no differences in pregnancy rates from first artificial insemination of heifers fed either diet (14 or 16\% CP) regardless of the RPMet level (Table 5). Likewise, no effect was observed on pregnancy rates from first to second insemination on the $14 \% \mathrm{CP}$ diet. However, when heifers were fed the $16 \% \mathrm{CP}$ diet, there was a tendency $(P=0.08)$ in improved pregnancy rates. No differences were observed in the mean number of services among cows fed the $14 \%$ CP diet. Days from calving to first, second or third insemination, as well as calving interval were also not different regardless of diet or RPMet levels (Table 6). 
Table 5

Pregnancy rates for heifers receiving different levels of rumen protected methionine in postpartum period

\begin{tabular}{lcccccccc}
\hline Diets & \multicolumn{3}{c}{$14 \% \mathrm{CP}$} & \multicolumn{7}{c}{$16 \% \mathrm{CP}$} & & & \\
Methionine g/d & 0 & 15 & 25 & 0 & 15 & 25 & SE & $P$ \\
\hline $\begin{array}{l}\text { Number of animals } \\
\text { Pregnancy rate \% }\end{array}$ & 9 & 9 & 9 & 9 & 9 & 9 & & \\
From first Al & $44(4) \pm 0.17$ & $44(4)$ & $44(4)$ & $33(3)$ & $55(5)$ & $55(5)$ & 0.17 & $\mathrm{~ns}$ \\
First and second Al & $55(5) \pm 0.19$ & $44(4)$ & $66(6)$ & $44(4)$ & $66(6)$ & $66(6)$ & 0.20 & $\mathrm{~ns}$ \\
Over whole $^{2}$ & $66(6) \pm 0.16$ & $55(5)$ & $66(6)$ & $66(6)$ & $66(6)$ & $77(7)$ & 0.16 & $\mathrm{~ns}$ \\
Number of service $^{1}$ & 1.5 & 1.4 & 1.33 & 1.8 & 1.2 & 1.4 & 0.3 & $\mathrm{~ns}$ \\
\hline
\end{tabular}

${ }^{1}$ Number of service for all cows, ${ }^{2}$ First, second and third Al

Table 6

Average days from calving to first, second and third AI for heifers receiving different levels of rumen protected methionine in postpartum period

\begin{tabular}{|c|c|c|c|c|c|c|c|c|}
\hline Diets & & $14 \%$ CP & & & $16 \% \mathrm{CP}$ & & & \\
\hline Methionine $\mathrm{g} / \mathrm{d}$ & 0 & 15 & 25 & 0 & 15 & 25 & SE & $P$ \\
\hline Days to first $\mathrm{Al}^{1}$ & $64(9)$ & $62(9)$ & $64(9)$ & $62(9)$ & $65(9)$ & $64(9)$ & 3 & ns \\
\hline Days to second Al & $87(5)$ & $87(5)$ & $85(5)$ & $82(5)$ & $84(4)$ & $91(4)$ & 4 & ns \\
\hline Days to third A I & $106(4)$ & $105(5)$ & $102(3)$ & $104(5)$ & $102(3)$ & $108(3)$ & 4 & ns \\
\hline Calving interval ${ }^{2}$ & $351(6)$ & $352(5)$ & $353(6)$ & $358(6)$ & $352(6)$ & $354(7)$ & 7 & ns \\
\hline
\end{tabular}

'average days from calving to first artificial insemination, ${ }^{2}$ calving interval for all heifers, number of animals in brackets

Present results agreed with Rogers et al. (1989) who reported that supplementation with RPMet did not effect reproductive performance of dairy cows. In a previous study, Fuquay et al. (1975) obtained a tendency to increased conception rate at first service when dairy cows were supplemented with $25 \mathrm{~g}$ methionine hydroxy analog/day during early lactation, while Polan et al. (1991) and Bobe (1997) observed that supplementation with RPMet did not alter the number of services per conception, days to first service, services per conception and calving interval in dairy cows. On the other hand, Ardalan et al. (2010) reported that supplementation of RPMet can improve reproductive performance of dairy cows.

Present results indicate that reproductive performance was not affected when RPMet was supplemented to both diets. Dairy cows usually may experience periods of negative energy balance and therefore may be at greater risk of reproductive/conception failure. Therefore, providing RPMet was expected to enable the higher-producing cows to maintain productivity but at reduced expenses of reproductive malfunction. It is possible that the limited number of cows in this study may have diminished the ability to detect a significant difference in reproductive parameters with non-normally distributed data like conception and pregnancy rates (Santos et al. 2001). Other possible factors are associated with the chance grouping of animals, semen quality or many other factors involved in reproductive efficiency (Fuquay et al. 1975).

It should be emphasized here that due to the short duration of the experimental period as well as the very limited number of heifers utilized throughout the experiment, present results might not be realistic or provide a good judgement. 
In conclusion, addition of RPMet at a level of $15 \mathrm{~g} / \mathrm{hd} / \mathrm{d}$ to the ration of dairy heifers produced a very limited effect on the studied parameters regardless of the CP level. However, addition of $25 \mathrm{~g} / \mathrm{hd} / \mathrm{d}$ RPMet to dairy heifers regardless of CP level increased milk yield, FCM, ECM and improved milk composition except milk protein content which was unaffected. Reproductive performance was not affected by RPMet supplementation at both dietary protein levels. However, results on reproductive performance are not certain.

\section{References}

AbuGhazaleh AA, Schingoethe DJ, Hippen AR, Kalscheur KF, Whitlock LA (2002) Fatty Acid Profiles of Milk and Rumen Digesta From Cows Fed Fish Oil, Extruded Soybeans or Their Blend. J Dairy Sci 85, 2266-2276

Ali CS, Islam-Ud-Din, Sharif M, Nisa M, Javaid A, Hashmi N, Sarwar M (2009) Supplementation of Ruminally Protected Proteins and Amino Acids: Feed Consumption, Digestion and Performance of Cattle and Sheep. Int J Agr Biol 11, 477-482

AOAC (1995) Official methods of analysis. 16th ed., Arlington, Virginia, USA

Ardalan M, Rezayazdi K, Dehghan-Banadaky M (2010) Effect of rumen-protected choline and methionine on physiological and metabolic disorders and reproductive indices of dairy cows. J Anim Physiol Anim Nutr (Berl) 94, 259-265

Armentano LE, Bertics SJ, and Ducharme GA (1997) Response of Lactating Cows to Methionine or Methionine Plus Lysine Added to High Protein Diets Based on Alfalfa and Heated Soybeans. J Dairy Sci 80, 1194-1199

Bobe $G$ (1997) Effects of dietary supplementation with protected methionine on reproductive efficiency of dairy cows. Dairy Report-lowa State University

Benefield BC, Patton RA, Stevenson MJ, Overton TR (2009) Evaluation of rumen-protected methionine sources and period length on performance of lactating dairy cows within Latin squares. J Dairy Sci 92, 4448-4455

Dinn NE, Shelford JA, Fisher LJ (1998) Use of the Cornell Net Carbohydrate and Protein System and RumenProtected Lysine and Methionine to Reduce Nitrogen Excretion from Lactating Dairy Cows. J Dairy Sci 81, 229-237

Edmonson AJ, Lean IJ, Weaver LD, Farver T, Webster G (1989) A Body Condition Scoring Chart for Holstein Dairy Cows. J Dairy Sci 72, 68-78

Fuquay J, McGee W, and Custer E (1975) Effect of methionine hydroxyl analog on postpartum interval and reproductive efficiency in dairy cattle. J Dairy Sci 58 (Suppl.), 139

Girard CL, Lapierre H, Matte JJ, Lobley GE (2005) Effects of Dietary Supplements of Folic Acid and RumenProtected Methionine on Lactational Performance and Folate Metabolism of Dairy Cows. J Dairy Sci 88, 660-670

Kudrna V, Illek J, Marounek M, Nguyen Ngoc A (2009) Feeding ruminally protected methionine to pre- and postpartum dairy cows: effect on milk performance, milk composition and blood parameters. Czech J Anim Sci 54, 395-402

Lara A, Mendoza GD, Landois L, Barcena R, Sánchez-Torres MT, Rojo R, Ayala J, Vega S (2006) Milk production in Holstein cows supplemented with different levels of ruminally protected methionine. Livest Sci 105, 105-108

Leonardi C, Stevenson M, Armentano LE (2003) Effect of Two Levels of Crude Protein and Methionine Supplementation on Performance of Dairy Cows. J Dairy Sci 86, 4033-4042

Madsen TG, Nielsen L, Nielsen MO (2005) Mammary nutrient uptake in response to dietary supplementation of rumen protected lysine and methionine in late and early lactating dairy goats. Small Rumin Res 56, 151-164

National Research Council (2001) Nutrient requirements of dairy cattle. 7th rev. ed., National Academy Press, Washington, D.C., USA 
Noftsger S, St-Pierre NR (2003) Supplementation of Methionine and Selection of Highly Digestible Rumen Undegradable Protein to Improve Nitrogen Efficiency for Milk Production. J Dairy Sci 86, 958-969

Overton TR, Lacount DW, Cicela TM, Clark JH (1996) Evaluation of a Ruminally Protected Methionine Product for Lactating Dairy Cows. J Dairy Sci 79, 631-638

Overton TR, Emmert LS, Clark JH (1998) Effects of Source of Carbohydrate and Protein and Rumen-Protected Methionine on Performance of Cows. J Dairy Sci 8, 221-228

Polan CE, Cummins KA, Sniffen CJ, Muscato TV, Vicini JL, Crooker BA, Clark JH, Johnson DG, Otterby DE, Guillaume B, Muller LD, Varga GA, Murray RA, Peirce-Sandner SB (1991) Response of Dairy Cows to Supplemental Rumen-Protected Forms of Methionine and Lysine. J Dairy Sci 74, 2997-3013

Rogers JA, Peirce-Sandner SB, Papas AM, Polan CE, Sniffen CJ, Muscato TV, Staples CR, Clark JH (1989) Production Responses of Dairy Cows Fed Various Amounts of Rumen-Protected Methionineand Lysine. J Dairy Sci 72, 1800-1817

Samuelson DJ, Denise SK, Roffler R, Ax RL, Armstrong DV, Romagnolo DF (2001) Response of Holstein and Brown Swiss Cows Fed Alfalfa Hay-Based Diets to Supplemental Methionine at Two Stages of Lactation. J Dairy Sci 84, 917-928

Santos JEP, DePeters EJ, Jardon PW, Huber JT (2001) Effect of Prepartum Dietary Protein Level on Performance of Primigravid and Multiparous Holstein Dairy Cows. J Dairy Sci 84, 213-224

Socha MT, Putnam DE, Garthwaite BD, Whitehouse NL, Kierstead NA, Schwab CG, Ducharme GA, Robert JC (2005) Improving Intestinal Amino Acid Supply of Pre- and Postpartum Dairy Cows with Rumen-Protected Methionine and Lysine. J Dairy Sci 88, 1113-1126

Socha MT, Schwab CG, Putnam DE, Whitehouse NL, Garthwaite BD, Ducharme GA (2008) Extent of Methionine Limitation in Peak-, Early-, and Mid-Lactation Dairy Cows. J Dairy Sci 91, 1996-2010

Steel RGD, Torrie JH (1986) Principles and procedures of statistics: A biometrical approach, 2nd ed., New York, USA

Trinact y J, Krizova L, Richter M, Cerny V, Riha J (2009) Effect of rumen-protected methionine, lysine or both on milk production and plasma amino acids of high-yielding dairy cows. Czech J Anim Sci 54, 239-248

Van Soest PJ, Robertson JB, Lewis BA (1991) Methods for Dietary Fiber, Neutral Detergent Fiber, and Nonstarch Polysaccharides in Relation to Animal Nutrition. J Dairy Sci 74, 3583-3597 